\title{
First report of citrus leaf blotch virus infecting orange and mandarin trees in Morocco
}

\author{
Mohamed Afechtal $^{1} \cdot$ Giuliana Loconsole $^{2} \cdot$ Maria Saponari $^{2} \cdot$ Raied Abou Kubaa $^{2} \odot$
}

Received: 4 January 2021 / Accepted: 12 February 2021 / Published online: 22 February 2021

(c) Società Italiana di Patologia Vegetale (S.I.Pa.V.) 2021

Keywords Citrus leaf blotch virus $\cdot$ RT-PCR $\cdot$ Morocco

During the late summer of 2019, a small scale field survey was conducted to assess the sanitary status of citrus orchards in Gharb region in the northwest of Morocco. A total of 30 symptomless citrus trees, belonging to six cultivars (Valencia Late, Washington Navel and Salustiana oranges, Common clementine, Nova mandarin and Eureka lemon) were randomly sampled from six orchards and screened for the presence of citrus tristeza virus (CTV), citrus psorosis virus ( $\mathrm{CPsV}$ ), citrus variegation virus (CVV) and citrus leaf blotch virus (CLBV). RT-PCR test using standard protocols was performed on total RNA preparations recovered from $0.2 \mathrm{~g}$ of leaf tissues process by RNeasy Plant Mini Kit (Qiagen, Germany). Results showed high infections by CPsV (46.7\%), and CVV (66.7\%) and lower infections by CLBV (13.3\%) whereas CTV was not detected. CPsV and CVV occur in Morocco (Afechtal 2018) while the presence of CLBV had not been reported yet. In this study, four citrus trees, two of cv. Nova and two of cv. Valencia Late were positive for CLBV. The latter two trees were also infected by CPsV. Detection of CLBV (the type species of the genus Citrivirus of the family Betaflexiviridae) was firstly assessed by a primer set targeting 456 bp in the RNA-dependent RNA polymerase (RdRp) gene and then confirmed by a primer set targeting the coat protein $(\mathrm{CP})$ gene (Vives et al. 2002). BLASTn analysis of the CLBV Moroccan isolates (MW115851-MW115854) showed 97.95-98.86\%, identities with the French isolate SRA-153 (AJ318061). To the best of our knowledge, this study represents the first report of the

Raied Abou Kubaa

raied.aboukubaa@ipsp.cnr.it

1 National Institute for Agricultural Research (INRA),

Regional Center of Kénitra, 14 rue Ibn Temmam, PO

Box 257, Kénitra, Morocco

2 Istituto Per La Protezione Sostenibile Delle Piante, UOS

Bari, Consiglio Nazionale Delle Ricerche, 70126 Bari, Italy occurrence of CLBV in Morocco and North Africa. Since CLBV can infect several host species including Citrus spp., sweet cherry, kiwifruit, peony and most recently mulberry tree, further investigations should address the prevalence, distribution and the impact of CLBV infections in Morocco.

\section{Declarations}

Ethics declarations The authors declare that they have no conflict of interest from this research, and that it doesn't contain any studies with human participants or animals.

\section{References}

Afechtal M (2018) Present status of virus and virus-like diseases of Citrus in Morocco. Integrated Control in Citrus Fruit Crops IOBC-WPRS Bulletin 132:215-220. Retrieved from https:// www.iobc-wprs.org/members/shop_en.cfm?mod_Shop_detail_ produkte $=186$

Vives MC, Galipienso L, Navarro L, Moreno P, Guerri J (2002) Citrus leaf blotch virus: a new Citrus virus associated with bud union crease on trifoliate rootstocks. International Organization of Citrus Virologists Conference Proceedings (1957-2010) 15(15):205-212. Retrieved from https://escholarship.org/uc/item/29c334f4

Publisher's Note Springer Nature remains neutral with regard to jurisdictional claims in published maps and institutional affiliations. 